\title{
RESEARCH PAPER \\ USING GIS FOR SPATIAL EXPLORATORY ANALYSIS OF BOREHOLE DATA: A FIRSTHAND APPROACH TOWARDS GROUNDWATER DEVELOPMENT
}

\author{
C. Gyamfi ${ }^{1}$, J. M. Ndambuki ${ }^{1}$, P. Y. Diabene ${ }^{2}$, G. E. Kifanyi ${ }^{1}$, A. Alexander ${ }^{1}$ and \\ C. R. Githuku ${ }^{1}$ \\ ${ }^{1}$ Department of Civil Engineering, Tshwane University of Technology, Pretoria, South Africa \\ ${ }^{2}$ WaterAid Ghana, P.O. Box KIA 16185, Accra \\ *Corresponding author: gyamficharles84@yahoo.com
}

\begin{abstract}
Groundwater is an inimitable resource that provides water to communities especially in arid and semi-arid regions. However, the spatial variability of the resource as well as the heterogeneity and complex nature of aquifer systems that store groundwater presents difficulties for groundwater development. Thus, understanding the spatial structure of aquifer characteristics could be used as a resourceful tool and as a first point of call towards groundwater development. The study investigated aquifer characteristics particularly on transmissivity and specific capacity to determine how aquifer characteristics could be used in making predictions for new sites that need to be identified for potential groundwater development. Prediction maps were developed for transmissivity and specific capacity using ordinary kriging J-Bessel and exponential semi variograms techniques. The study revealed that $28 \%$ of the study area had high potential for groundwater development with transmissivity ranges of $34.40-46.52 \mathrm{~m}^{2} / d$. Equally, viable areas of $16 \%$ and $20 \%$ were identified with transmissivities of $27.99-34.39 \mathrm{~m}^{2} / \mathrm{d}$ and $13.07-19.47 \mathrm{~m}^{2} /$ $d$ respectively. Based on specific capacity, $21 \%$ of the study area was identified to have groundwater development potential with corresponding specific capacity of $13.54-20.7 \mathrm{~m}^{2} / \mathrm{d}$. Similarly, $24 \%$ and $34 \%$ of the study area were also identified to be good for the exploitation of groundwater with corresponding specific capacities of $8.74-13.55 \mathrm{~m}^{2} / \mathrm{d}$ and $5.52-8.74 \mathrm{~m}^{2} / \mathrm{d}$ respectively. In terms of spatial structure, transmissivity was found to be variable compared to specific capacity. The application of Geographic Information Systems (GIS) is thus considered to be an immeasurable tool that could be used in mapping aquifer characteristics that can serve as firsthand information for groundwater development.
\end{abstract}

Keywords: Spatial, Groundwater, Transmissivity, Specific capacity, Kriging, Semivariogram

\section{INTRODUCTION}

Water remains the single most important resource for sustaining life and the ecosystem.
For this reason, competition for water resources will continue to exacerbate. Numerous studies have alluded to the looming water scarcity with 
its inherent conflicts (UNDP, 2006; Behr, 2008; NRDC, 2010) and accompanying poverty, diseases and hunger (Gleick, 1998). It is in recognition of the anticipated future water challenges that current researches are focusing on strategies to mitigate future water crisis. Key in this area has been the studies on climate change and its ramification on water resources of the world. Findings from climate change studies (Adams and Peck, 2008; Solomon et al., 2007) have buttressed the issue of water scarcity with substantial consequence on African countries (IPCC, 2007).

As a coping strategy, developing countries in Africa are exploring alternative means for sustainable water supply. Crucial in this regard, are the considerations given to the development of groundwater systems for community water supply. This clearly affirms the assertion made by MacDonald and Davies (2002) that groundwater resources are the most reliable for meeting community water demand. This notwithstanding, due to the somewhat low technologies that are used in groundwater exploration in developing countries, considerable time and money gets wasted with unsuccessful exploration occurring most of the time. It should be noted however that these groundwater developments are carried out by developing countries that already have their national budgets overburdened and hence cannot afford to be carrying out unsuccessful groundwater exploration. A study conducted by Diabene and Gyamfi (2013) recommended that, thorough investigations of aquifer characteristics be carried out before any groundwater development. In view of this, developing strategies that are capable of critiquing aquifer characteristics and ensuring high success rate in groundwater exploration becomes essential.

To this end, the feasibility of using geographic information systems (GIS) as tools in exploring aquifer characteristics of existing boreholes becomes essential. The objectives of this study were therefore to (i) carry out exploratory analysis on borehole data using GIS and (ii) develop prediction maps that could be used in making first hand location choices for detailed field investigations for future groundwater exploration activities. This approach should not in any case be seen as a substitute for detailed field investigations but rather a means of obtaining first hand information as to which locations needs further field investigations for the provision of boreholes for community water supply.

\section{MATERIALS AND METHOD}

\section{Description of study area}

Bawku West District (Fig. 1) of the Upper East Region (UER) of Ghana was selected for the study. The selection of this location was informed by the lack of water facilities that exist in this area and the difficulty encountered during groundwater exploration activities. Geographically the district lies between latitude $10^{\circ}$ $33^{\prime} \mathrm{N}$ and $11^{\circ} 7^{\prime} \mathrm{N}$ and longitudes $0^{\circ} 20^{\prime} \mathrm{W}$ and $0^{\circ} 36^{\prime} \mathrm{W}$. The district occupies approximately a total land area of $1,070 \mathrm{~km}^{2}$, which constitutes about $12 \%$ of the total land area of the UER (GSS, 2014). The population of the district as at 2010 was 94,034 and forms about $9 \%$ of the regional population (GSS, 2014). The main source of water for inhabitants of this district is groundwater (GSS, 2013). A study conducted by Gyau-Boakye and Dapaah-Siakwan (1999) in the UER revealed that $76.8 \%$ of domestic water uses were dependent on groundwater. Climatic conditions in this area are characterized by a unimodal rainfall pattern starting in May and lasting till October with rainfall values ranging between $800 \mathrm{~mm}$ to $1000 \mathrm{~mm}$ (Forkuor et al., 2013). The temperature in Bawku West ranges between $14^{\circ} \mathrm{C}$ at night to $35^{\circ} \mathrm{C}$ during the day with very low relative humidity. The relief of the district is generally flat to gently undulating with slopes ranging from 1 - 5\% (GSS, 2014).

Found in the district are the two tributaries of the Volta River namely, the White and Red Volta. These rivers overflow their banks during the rainy season but dry out in the dry season. Groundwater in the study area occurs in two 

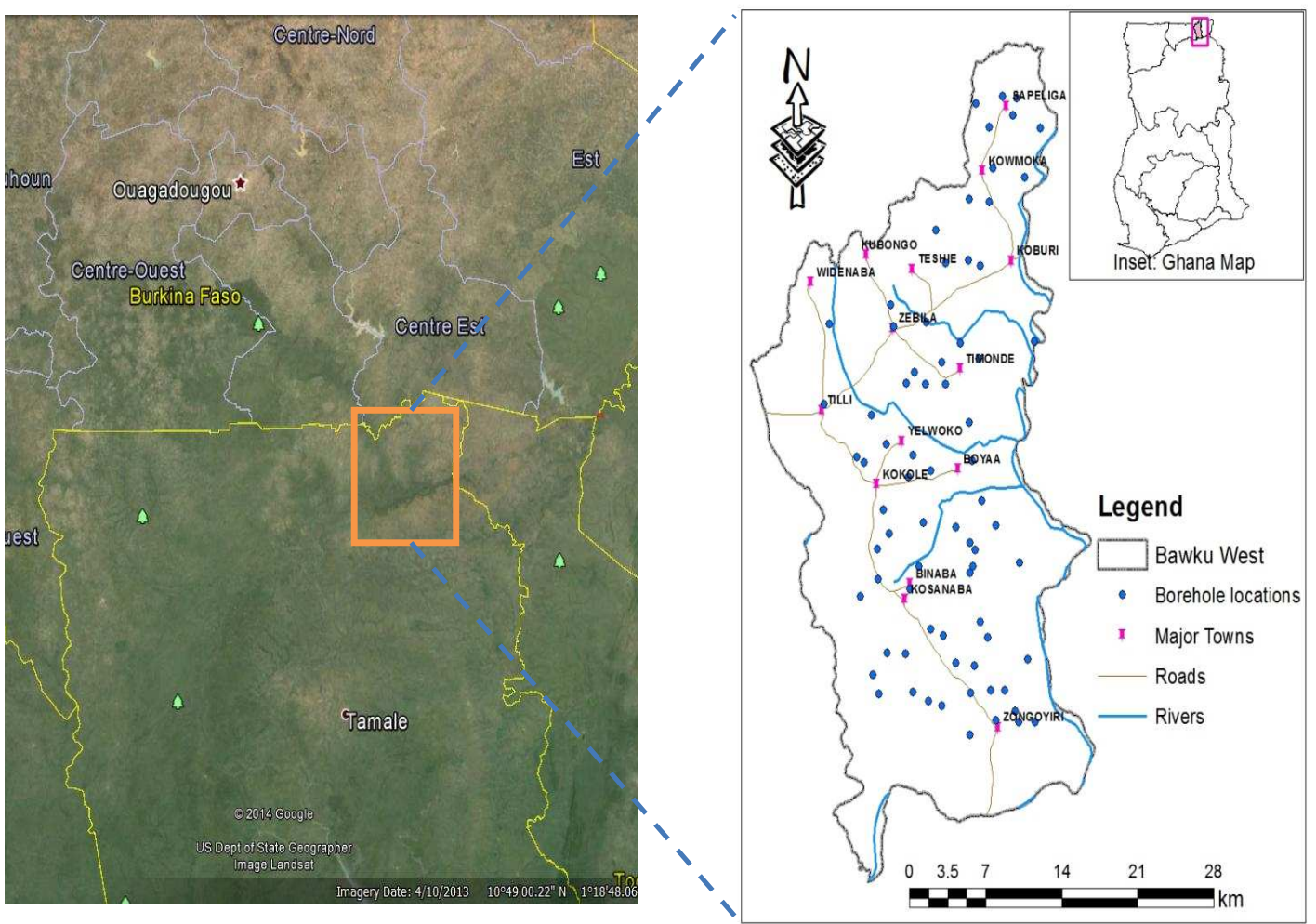

Fig. 1: Location of study area showing borehole locations

main hydrogeological formations; basement rocks and consolidated sedimentary rocks (Dapaah-Siakwan and Gyau-Boakye, 2000). According to Forkuor et al. (2013) schist, phyllite, migmatite, granite-gneiss and quartzite make up the dominant component of the basement hydrogeological formations. The aridity index which expresses the ratio of the annual precipitation to potential evaporation is estimated to be about 0.33 for the district. According to UNCCD (1997) the district is classified to be within the dry land zone of Ghana.

\section{Hydrogeological setting}

Two major formations dominate the geology of Ghana (Obuobie and Barry, 2010). These are the basement crystalline rocks which form 54\% of the country and the Paleozoic consolidated formation which covers $45 \%$. The remaining
$1 \%$ is underlain by minor geological formations including Cenozoic, Mesozoic and Paleozoic sedimentary strata along narrow belts on the coast and Quatenary alluvium along major stream courses. The crystalline rocks are comprised of a variety of Precambrian igneous and metamorphic rocks that are subdivided into geohydrologic provinces namely the Birimian, granite, Dahomeyan, Togo, Buem and Tarkwaian rock formations (Dapaah-Siakwan and Gyau-Boakye, 2000). The rocks types are mainly made up of gneiss, phyillite, schist, migmatite, quartzite and granite-gneiss which are impermeable.

According to Dapaah-Siakwan and GyauBoakye (2000), the occurrence of groundwater in this formation is characterized by the development of secondary porosity, which is as a 


\section{Gyamfi et al.}

result of weathering and fracturing. Borehole yields in these weathered formations are dependent on rainfall thus the potential for groundwater is non-existent or very low when the depth of weathering is thin or where there are no fractures. Studies conducted by DapaahSiakwan and Gyau-Boakye (2000) states that the Paleozoic consolidated sedimentary formations are locally called the Voltaian formation and consist mainly of sandstone, shale, arkose, mudstone, sandy and pebbly beds and limestone. This formation can be sub-grouped into the upper, middle and lower Voltaian based on lithology and field relationships (Obuobie and Barry, 2010). The upper Voltaian consists of massive and thin-bedded quartzite sandstones, which are interbeded with shale and mudstone in some areas. The middle Voltaian (Obusum and Oti Beds) mostly comprise of shales, sandstones, arkose, mudstones and siltstones. The lower Voltaian consists of massive quartzite sandstone and grit (Obuobie and Barry, 2010). The occurrence of groundwater in the Voltaian system is associated with secondary porosity.

Generally, groundwater potential in the Voltaian System is lower than the Basement Complex (Dapaah-Siakwan and Gyau-Boakye, 2000). In the Cenozoic and Mesozoic sediments formation, three aquifers can be found (Obuobie and Barry, 2010) with depth ranging from $2 \mathrm{~m}$ to $4 \mathrm{~m}$. The first aquifer is unconfined and occurs in the recent sand very close to the coast containing fresh meteoric water. The second aquifer is either semi-confined or confined, occurs mainly in the red continental deposits of sandy clays and gravels and usually contains saline water. The depth of this aquifer varies from $6 \mathrm{~m}$ to $120 \mathrm{~m}$. The limestone aquifer is the third and last aquifer with depth varying from $120 \mathrm{~m}$ and $300 \mathrm{~m}$. Groundwater is fresh in this aquifer and occurs under artesian condition with yield ranging from $4.5 \mathrm{~m}^{3} / \mathrm{h}$ to $54 \mathrm{~m}^{3} / \mathrm{h}$ (Dapaah-Siakwan and Gyau-Boakye, 2000).

\section{Exploratory analysis and predictions of po- tential areas}

Borehole data on 74 boreholes were used for this study. The data were acquired from borehole logs available for existing boreholes in the study location. Key variables that were considered to influence aquifer characteristics for sustainable water supply were selected and include transmissivity $\left(\mathrm{m}^{2} / \mathrm{d}\right)$ and specific capacity $\left(\mathrm{m}^{2} / \mathrm{d}\right)$ of each borehole. Geostatistical methods used in the exploratory analysis of data were distribution pattern of variables, trend analysis and theoretical semivariogram fitting. Explorations in the distribution of variables were carried out using histogram and normal QQ plot. These methods gave indication as to the nature of distribution of a variable under consideration. In the absence of a normal distribution, a transformation of the variable became necessary in order to enable further analysis. Trend analysis was done on all variables to detect the existence or otherwise of spatial coordinate variation. Semivariogram, a measure of the relation of data points within a particular variable to each other with respect to distance was used to assess the spatial dependency of the selected variables. The theoretical semivariogram as formulated by Matheron (1963) is given by:

$\gamma(h)=\frac{1}{z N(h)} \sum_{i=1}^{N(h)}\left\{z\left(x_{i}\right)-z\left(x_{i}+h\right)\right\}^{2}$

where,

$\gamma(h)$ is semi-variance at lag $\mathrm{h}$

$\mathrm{h}$ is distance (lag)

$\mathrm{x}$ is position in one dimensional space

$\mathrm{N}(\mathrm{h})$ is Pairwise Euclidean distance

In predicting values for unsampled locations, the empirical semivariogram was fitted with a theoretical semivariogram model. Geostatistical wizard provided numerous fitting models which were explored and compared. The best fitting model was selected based on statistical measures of the root mean square standardized error (RMSSE). The closer the RMSSE is to 1, the better the predictive power of the model to the measured values of the variable under cons- 
ideration (Castrignanò et al., 2007).From the best fitted theoretical models, the spatial structure of each variable was determined using the method described by Cambardella et al. (1994). According to Cambardella et al. (1994) the nugget $\left(\mathrm{C}_{\mathrm{o}}\right)$ to sill $\left(\mathrm{C}_{\mathrm{o}}+\mathrm{C}_{1}\right)$ ratio can be used to describe the spatial dependency of soil properties. Nugget/Sill ratio of $<0.25,0.25-0.75$ and $>0.75$ were classified as having strong, moderate and weak spatial structure respectively. The best fit model selected for each variable was subsequently used in generating prediction maps employing the ordinary kriging interpolator. All data analysis and prediction maps were carried out based on the flow chart in Fig. 2 and ArcGIS 10.1.

\section{RESULTS AND DISCUSSION}

\section{Histogram and QQ plot analysis}

Fig. 3 shows the distribution pattern of transmissivity and specific capacity using a histogram. An examination of the plot indicates that transmissivity and specific capacity are positively skewed with skewness coefficients of 1.87 and 2.43 respectively. According to Oliver and Webster (2014), if the skewness coefficients exceed 1 , then fitting a three parameter log normal curve is required. As a result, transmissivity and specific capacity data were logtransformed to enable model fitting. The logtransformation was used due to the considerable statistics of measure (mean and median) it gives (Fig. 4). After the log transformation

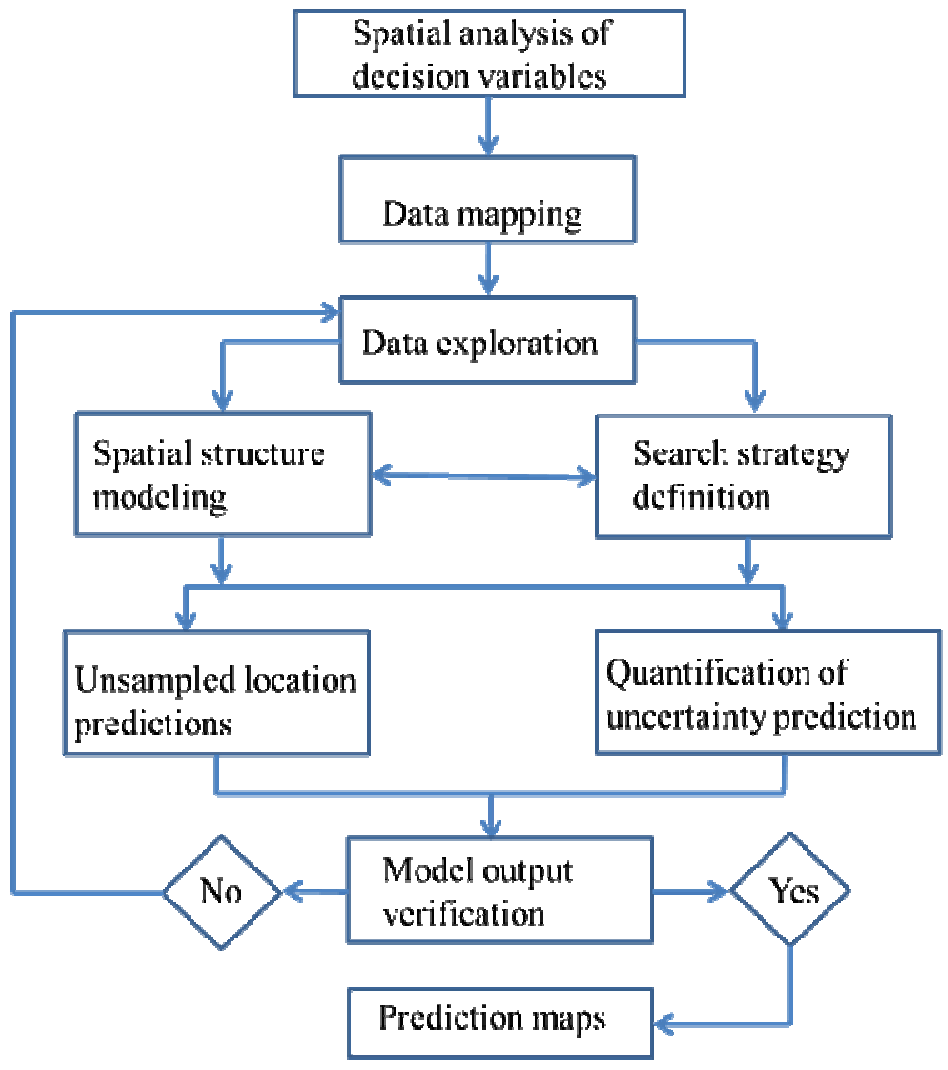

Fig. 2: Spatial data exploration and prediction flow chart

Journal of Science and Technology @ KNUST April 2016 

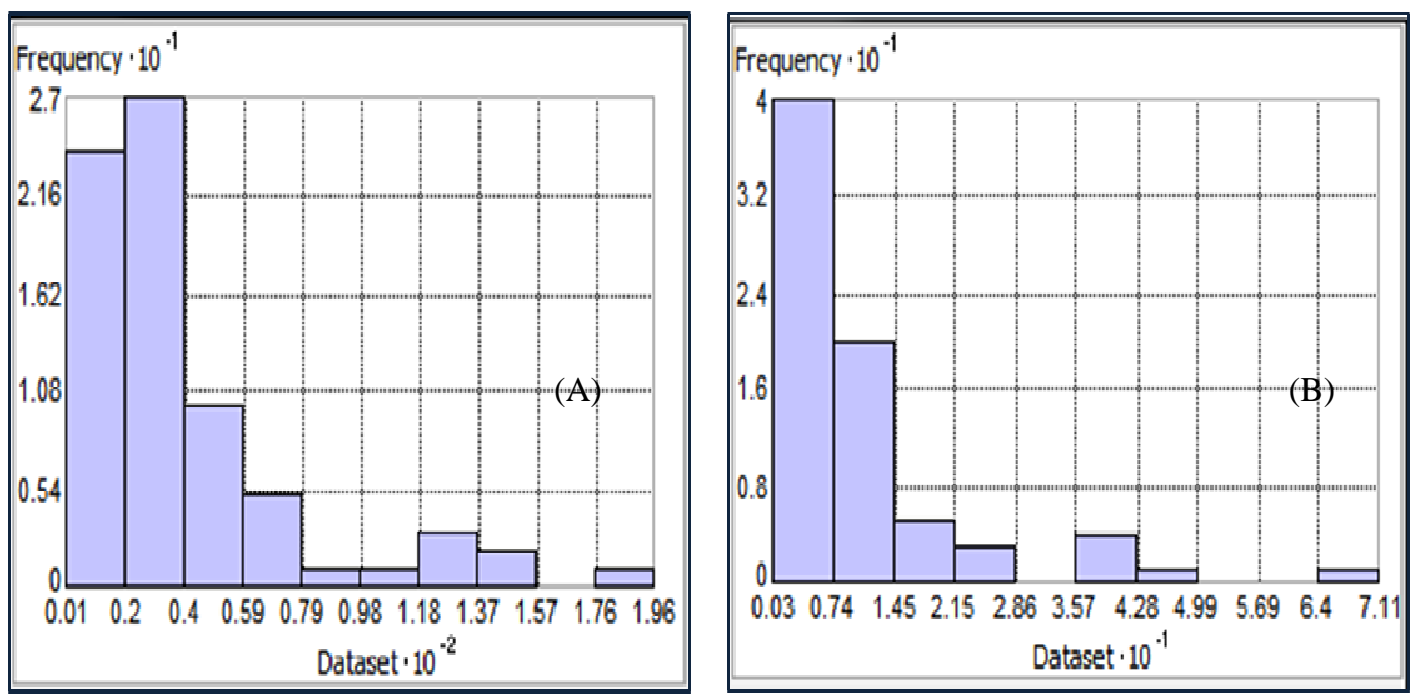

Fig. 3: Histogram for transmissivity (A) and specific capacity (B)
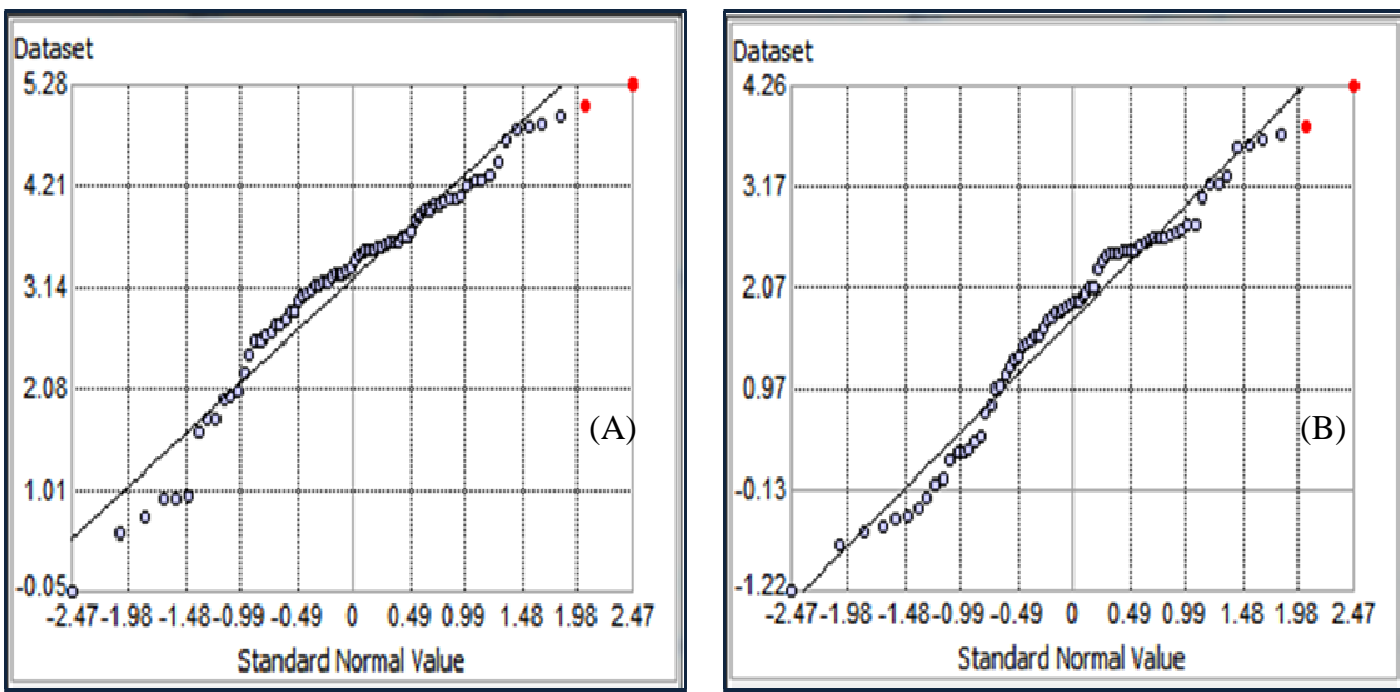

Fig. 4: Fitting of lognormal distribution to transmissivity (A) and Specific capacity (B) with red dots indicating outliers

the mean and median which are measures of distribution, compared well with each other for transmissivity and specific capacity (Table 1). This is an indication that both transmissivity and specific capacity data are log-normally distributed. This finding is in agreement with previous observations made (Chen et al., 2011; Razack and Huntley, 1991; Aboufirassi and 
Table 1: Statistics on original and $\log$ transformed transmissivity and specific capacity data

\begin{tabular}{rcccccccc}
\hline & \multicolumn{4}{c}{ Original data } & \multicolumn{4}{c}{ Log-transformed data } \\
\hline & Skewness & Kurtosis & Mean & Median & Skewness & Kurtosis & Mean & Median \\
& & & & & & & & \\
Transmissivity $\left(\mathrm{m}^{2} / \mathrm{d}\right)$ & 1.87 & 6.69 & 40.39 & 29.47 & -0.79 & 3.57 & 3.23 & 3.38 \\
Specific capacity $\left(\mathrm{m}^{2} / \mathrm{d}\right)$ & 2.43 & 10.07 & 10.7 & 6.72 & -0.39 & 2.48 & 1.74 & 1.90 \\
\hline
\end{tabular}

and Marino,1984; Rousselot, 1976). Examination of the histograms revealed about $89 \%$ of borehole data having transmissivities within the range of $1 \mathrm{~m}^{2} / \mathrm{d}$ to $79 \mathrm{~m}^{2} / \mathrm{d}$. On the other hand, $92 \%$ of the existing boreholes recorded values of specific capacity in the range of $0.3 \mathrm{~m}^{2} / \mathrm{d}$ to $28.6 \mathrm{~m}^{2} / \mathrm{d}$. However, a proportion of about $2.70 \%$ of the studied boreholes exceeded $150 \mathrm{~m}^{2} / \mathrm{d}$ and $42.8 \mathrm{~m}^{2} / \mathrm{d}$ for transmissivity and specific capacity respectively. These boreholes were therefore considered as outliers (Fig. 4).

From Fig. 4, it is evident that, transmissivity and specific capacity are log-normally distributed with data points clustering around the standard normal line.

\section{Trend analysis}

A marginal trend was observed in both transmissivity and specific capacity (Fig. 5). Transmissivity increases in the east-west direction and exhibits a gradual trend in the north-south direction. The trend observed in transmissivity cannot be said to be a strong one. With regards to specific capacity, a trend was observed in the east-west direction with virtually no trend in the north-south direction. Although low trajectories were recorded, it is suggestive of the fact that both transmissivity and specific capacity are anisotropic. The anisotropy of transmissivity and specific capacity should therefore be taken into consideration during the exploration phase of groundwater development bearing in mind the particular direction with a noticeable trend. A similar study conducted by Chen et al., (2011) also indicated that aquifer transmissivity is anisotropic.

\section{Semivariogram analysis}

In selecting the best fit model for the ordinary kriging semivariogram, the spherical, exponential, gaussian, K-Bessel and the J-Bessel models were compared. The comparison results indicated J-Bessel as the best fit model for transmissivity (Fig. 6a) while specific capacity was best modelled by the Exponentialsemivariogram (Fig. 6b). Summary of the model comparison is presented in Table 2. The nugget/sill ratio (Table 3) gave indication of weak spatial dependency for transmissivity whilst moderate for specific capacity. In other words, there is spatial structure variability for transmissivity but not specific capacity.

\section{Predicting potential areas for groundwater development}

In line with the study objectives, prediction maps (Fig. 7) were generated using the best fit models already discussed. The purpose of the prediction maps was to offer firsthand information on the general perspective of aquifer characteristics and to indicate potential areas for groundwater development.

Transmissivity predictions revealed that about $28 \%$ of the study area is under laid by aquifers with transmissivity ranging from $34.40-46.52$ $\mathrm{m}^{2} / \mathrm{d}$. Equally important were the $16 \%$ and $20 \%$ of the study area that were found to have transmissivities within the range $27.99-34.39 \mathrm{~m}^{2} / \mathrm{d}$ and $13.07-19.47 \mathrm{~m}^{2} / \mathrm{d}$ respectively. Based on specific capacity, $21 \%$ of the study area was 

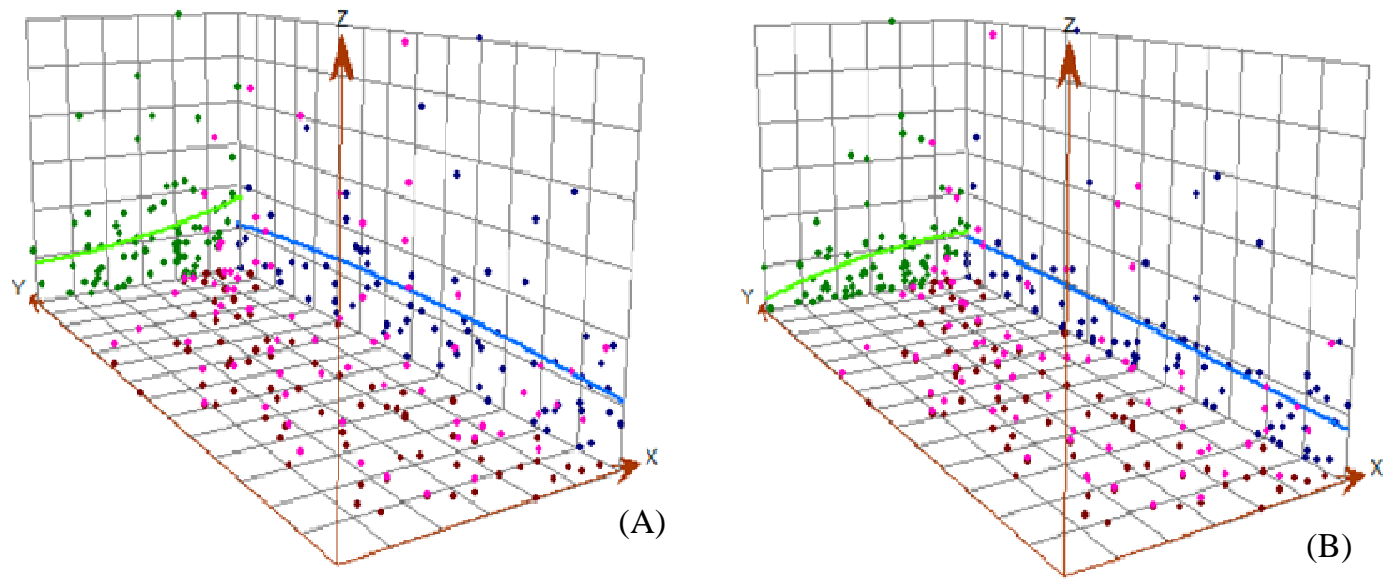

Fig. 5: Dependency of transmissivity (A) and specific capacity (B) on spatial coordinates
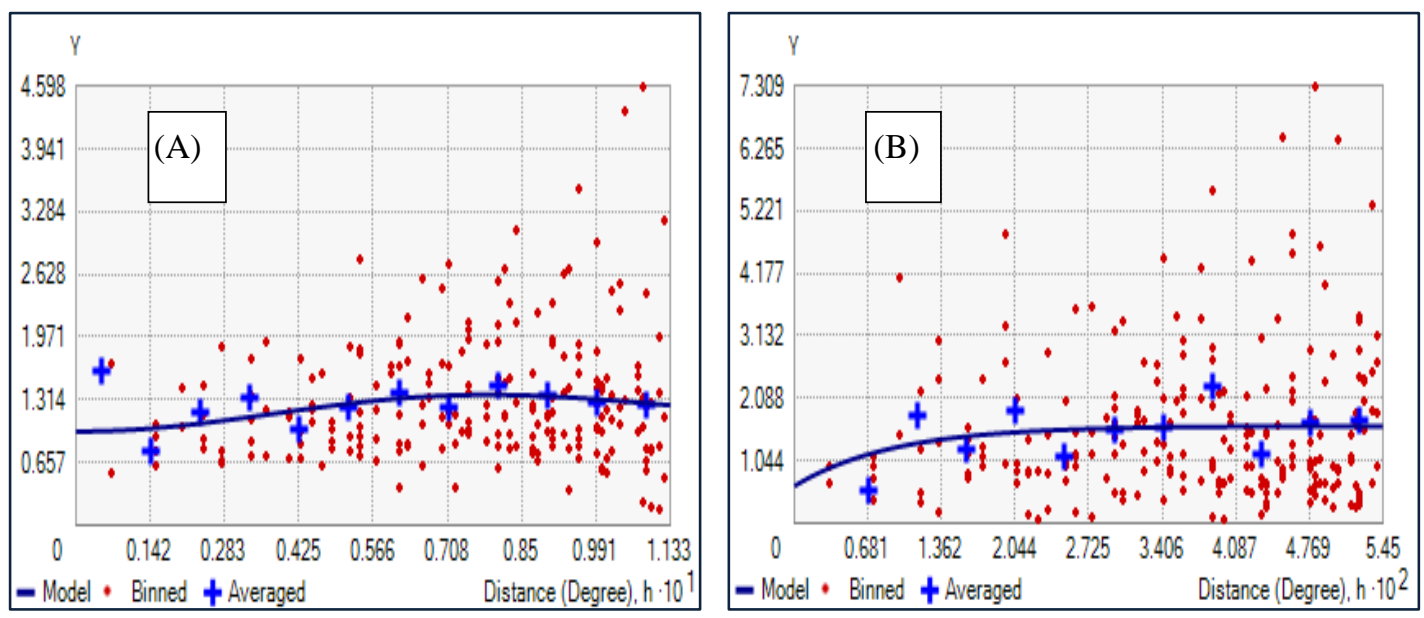

Fig. 6: J-Bessel (A) and Exponential (B) semivariogram for transmissivity and specific capacity respectively

identified to be potential areas with corresponding specific capacity of $13.54-20.7 \mathrm{~m}^{2} / \mathrm{d}$. Accordingly, $24 \%$ and $34 \%$ of the study area were identified to be good for the exploitation of groundwater with corresponding specific capacities of $8.74-13.55 \mathrm{~m}^{2} / \mathrm{d}$ and $5.52-8.74$ $\mathrm{m}^{2} / \mathrm{d}$ respectively.
Findings of the study indicates that based on transmissivity, generally about $64 \%$ of the study area could be considered as potential areas for further groundwater investigations. Conversely, if specific capacity is used as the selection criteria, then about $79 \%$ of the study area could be considered potential for ground- 
Table 2: Theoretical semivariogram model comparison for transmissivity and specific capacity

\begin{tabular}{lcc} 
Model & Transmissivity $\left(\mathbf{m}^{2} / \mathbf{d}\right)$ & Specific capacity $\left(\mathbf{m}^{2} / \mathbf{d}\right)$ \\
\hline & RMSSE & RMSSE \\
Spherical & 0.63 & 0.62 \\
Exponential & 0.61 & 0.72 \\
Gaussian & 0.63 & 0.63 \\
K-Bessel & 0.63 & 0.62 \\
J-Bessel & 0.66 & 0.71 \\
\hline
\end{tabular}

Table 3: Spatial structure of transmissivity and specific capacity

\begin{tabular}{lccccc}
\hline \multicolumn{1}{c}{ Variable } & Model & Nugget $\left(\mathbf{C}_{\mathbf{0}}\right)$ & Sill $\left(\mathbf{C}_{\mathbf{0}}+\mathbf{C}_{\mathbf{1}}\right)$ & $\mathbf{C}_{\mathbf{0}} / \mathbf{C}_{\mathbf{0}}+\mathbf{C}_{\mathbf{1}}$ & $\begin{array}{c}\text { Spatial } \\
\text { Structure }\end{array}$ \\
\hline Transmissivity $\left(\mathrm{m}^{2} / \mathrm{d}\right)$ & J-Bessel & 0.98 & 1.26 & 0.78 & Weak \\
Specific Capacity $\left(\mathrm{m}^{2} / \mathrm{d}\right)$ & Exponential & 0.62 & 1.63 & 0.38 & Moderate \\
\hline
\end{tabular}
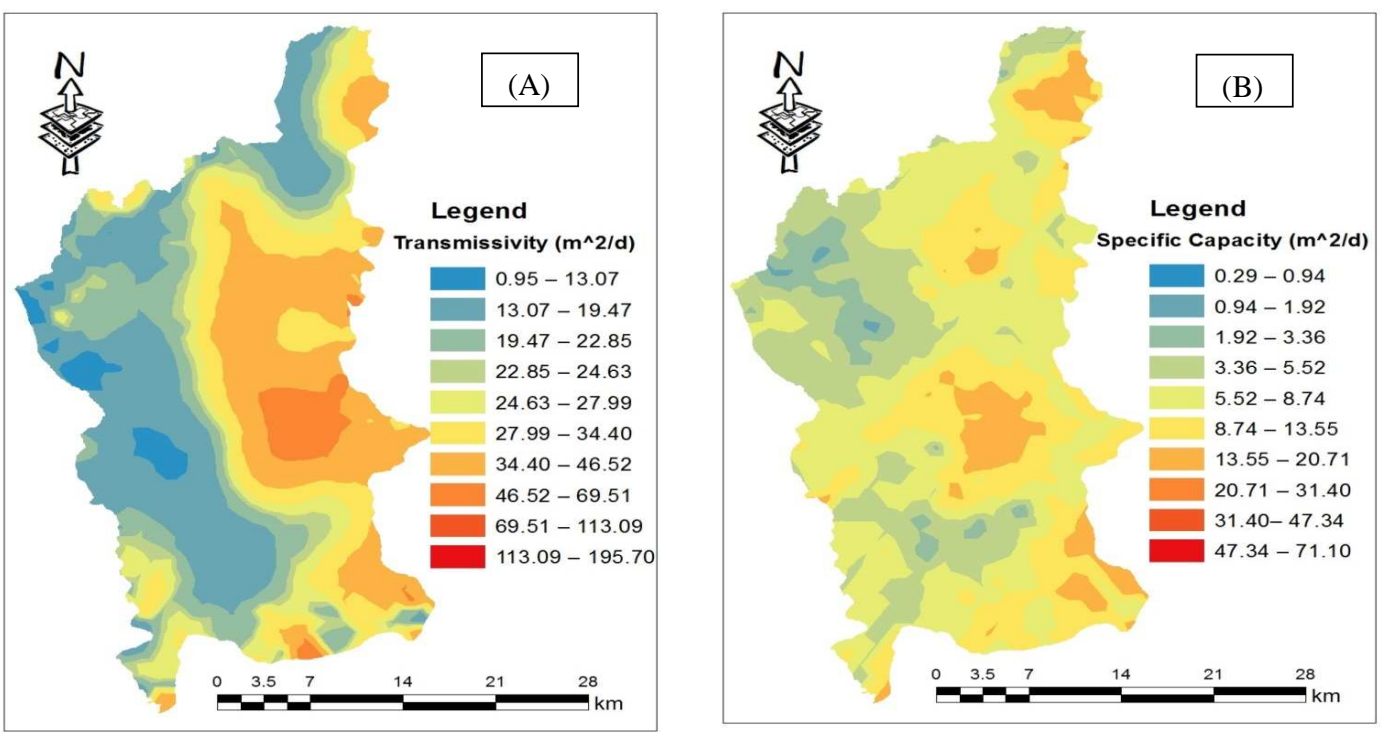

Fig. 7: Prediction map for Transmissivity (A) and Specific capacity (B) 
water development.

\section{CONCLUSION}

Through the use of geostatistical tools, it is evident that borehole data could be critiqued for the existence of trend, spatial variability of aquifer characteristics and predicts potential areas for groundwater development. In this study, the aquifer characteristics selected included transmissivity and specific capacity. The best fit model for predicting transmissivity in unsampled locations was the J-Bessel semivariogram. This model indicated that transmissivity had a weak spatial structure and had an east-west trend with respect to spatial coordinates (anisotropic), however the trend observed was considered to be insignificant. The exponential semivariogram best predicted unsampled location values for specific capacity. It described specific capacity as having a moderate spatial structure as well as being anisotropic (east-west direction). In the same vein, as considered in the case of transmissivity, the trend observed was insignificant. It is deduced however that, both transmissivity and specific capacity exhibited trends in the east-west direction but same cannot be said for the north-south direction.

Based on transmissivity, about $64 \%$ of the study area could be classified as suitable for further groundwater investigations. On the other hand, about 79\% of the study area is good for groundwater development if location selection should be based on specific capacity.

From the foregone discussions, it is evidently clear, how geographic information systems can contribute immensely to the understanding of aquifer characteristics. In using the prediction maps, fair judgments could be made as to the locations that might need further detailed investigations for groundwater development. This approach which gives firsthand insight into mapping potential areas for groundwater development should be adopted and explored to the advantage of community water supply systems.
It is recommended however that, transmissivity and specific capacity maps should be used conjunctively to aid in the optimal selection of potential areas for further groundwater investigations.

\section{REFERENCES}

Aboufirassi, M. and Marino, M. A. (1984). Cokriging of aquifer transmissivity from field measurements of transmissivities and specific capacity. Mathematical Geology, 16 (1):19-35.

Adams, R. M. and Peck. D. E. (2008). Effects of Climate Change on Drought Frequency: Impacts and Mitigation Opportunities. In: Mountains, Valleys, and Flood Plains: Managing Water Resources in a Time of Climate Change. A. Dinar and A. Garrido(eds). Routledge Publishing.

Behr, P. (2008).Looming water crisis: Is the world running out of water. Global Researcher, 2 (2): 27-56.

Cambardella, C. A., Moorman, T. B., Novak, J. M., Parkin, T. B., Karlen, D. L., Turco, R. F. and Konopka, A. E. (1994). Field-scale variability of soil properties in central Iowa soils. Soil Science Society of America Journal, 58 (5): 1501-1511.

Castrignanò, A., Cherubini, C., Giasi Consetta, I., Musci, F. and Pastore, N. (2007). Multivariate geostatistical and natural attenuation model approach for remediation of chlorinated compounds, WSEAS Transaction on Environment and Development, 5(3): 90 -98 .

Chen, Z, Grasby, S.E. and Osadetz, K. G. (2011). Geological controls on regional transmissivity anisotropy. Geofluids, 11(2): 228-241.

Dapaah-Siakwan, S. and Gyau-Boakye, P. (2000). Hydrogeologic framework and borehole yields in Ghana. Hydrogeology Journal, 
8(4): 405-416.

Diabene, P.Y. and Gyamfi, C. (2013). Groundwater potential for rural water supply: a sustainability assessment of boreholes in the Bawku West district, Ghana. Journal of Environmental Science and Water Resources, 3 (5): $110-117$

Forkuor, G., Pavelic, P., Asare, E. and Obuobie, E. (2013). Modelling potential areas of groundwater development for agriculture in northern Ghana using GIS/RS'. Hydrological Sciences Journal, 58(2): 437-451

GSS (2013). 2010 Population and Housing Census: Regional Analytical Report, Upper East Region. Accessed on $15^{\text {th }}$ October, 2014 from http://www.statsghana.gov.gh/

GSS, (2014). 2010 Population and Housing Census: District Analytical Report. Bawku Municipality. Accessed on $15^{\text {th }}$ March, 2016 from http://www.statsghana.gov/ docfiles/2010_District_Report/upper\% 20East/Bawku\%20Municipality.pdf

Gleick, P. H. (1998). The World's Water 19981999. Biennial Report on freshwater resources. Washington DC: Island Press.

Gyau-Boakye, P. and Dapaah-Siakwan, S. (1999). Groundwater: Solution to Ghana's rural water supply industry. Journal of the Ghana Institution of Engineers. Accessed on $18^{\text {th }}$ October, 2014 from http:// africantechnologyforum.org/GhIE/GhIE.htm.

IPCC, (2007). Climate change 2007: Synthesis report.

MacDonald, A. M. and Davies, J. (2002). A brief review of groundwater for rural water supply in Sub-Saharan Africa, British Geological Society, Nottingham, UK.

Matheron, G. (1963). Principles of geostatistics. Economic Geology, 58(8): 1246-1266.
NRDC, (2010). Climate change and water resources management: Adaptation strategies for protecting people and the environment. Accessed on $28^{\text {th }}$ October 2014 from http:// w w w. n r d c.org/water/files/ waterandclimate.pdf

Obuobie, E. and Barry, B. (2010). Groundwater in sub-Saharan Africa: Implications for food security and livelihoods, Ghana Country Status on Groundwater, Final Report.

Oliver, M. A. and Webster, R. (2014). A tutorial guide to geostatistics: Computing and modeling variograms and kriging. Catena, 113: 56-69.

Razack, M. and Huntley, D. (1991). Assessing transmissivity from specific capacity in a large and heterogenous alluvial aquifer. Groundwater, 29(6): 856-861.

Rousselot, D. (1976). Proposition pour une loi de distribution des permeabilities ou transmissivities, Rapport Bur. Rech. Geol. Minieres Serv. Geol, Jura - Alpes, Lyon (France).

Solomon, S., Qin, D., Manning, M., Chen,Z., Marquis, M., Averyt, K.B., Tignor, M. and Miller, H. L. (eds.) (2007). Climate Change 2007: The Physical Science Basis. Contribution of Working Group I to the Fourth Assessment Report of the Intergovernmental Panel on Climate Change. Cambridge University Press, Cambridge, U.K.

UNCCD, (1997). Drylands, People and landuse. Accessed on $18^{\text {th }}$ October, 2014 from http://www.fao.org/docrep/012/i0372e/ i0372e01.pdf.

UNDP, (2006). Summary Human Development Report. Beyond scarcity: Power, poverty and the global water crisis. Accessed on $5^{\text {th }} \mathrm{No}$ vember, 2014 from http://www.undp.org/ content/undp/en/home/librarypage/hdr/ human-development-report-2006. html. 